\title{
IRRIGATION SCHEDULING FOR SOME WHEAT CULTIVARS THROUGH PAN EVAPORATION NORMS AND ITS EFFECT ON GROWTH, YIELD AND WATER USE EFFICIENCY
}

\author{
Foaad, A.F. Khalil*, Gamal A. El-Shaarawy** and HasanY.M. Hasan* \\ *Water Requirements and Field Irrigation Research Department; Soil, Water, and \\ Environment Research Institute; Agricultural Research Center; Egypt \\ **Wheat Res. Dept., Field Crops Res. Instit., ARC, Egypt.
}

\section{ABSTRACT}

A field experiment was conducted during two successive seasons of 2003/2004 and 2004/2005 at Giza Agric. Res. Station. The study aimed to identify the most effective coefficient of daily pan evaporation records (selected from 1.4, 1.2, 1.0 and 0.8) in scheduling the irrigation for some wheat cultivars namely Sids 1, Gemmeiza 7, Sakha 93 and Giza 168, in order to maximize crop and water productivity. The obtained results could be summarized as follows.

1- The growth characters of plant height and leaf area index were significantly influenced due to the adopted irrigation regimes and generally, tended to increase as the coefficient of pan evaporation records increased. In addition, Gemmeiza 7 cultivar surpassed the other tested wheat cultivars to increase such characters.

2- № of grains/spike and 1000-grain weight traits exhibited similar trends since scheduling irrigation according to 1.2 pan evaporation coefficient(PEC) resulted higher figures for such characters. Gemmeiza 7 surpassed the other tested wheat cultivars to increase such traits. The trait of No. of spikes $/ \mathrm{m}^{2}$ exhibited different trend since higher values were recorded under 1.0 and 1.2 PEC in the first and second seasons, respectively. Sids 1 and Gemmeiza 7 cultivars were superior to produce the highest No. of spikes $/ \mathrm{m}^{2}$ in the first and second seasons, respectively.

3- Straw yield seemed to increase with increasing the value of PEC and Gemmeiza 7 cultivar is still superior to increase such trait more than the other tested wheat cultivars. The highest grain yield was obtained as irrigation was practiced according to 1.2 PEC and tended to reduce under the other assessed PEC treatments and this finding was true in the two seasons.

4- All of agronomic, yield and yield components traits were significantly influenced as the adopted irrigation regimes interacted with the wheat cultivars under study.

5- Number of applied irrigations and water consumptive use (CU) were increased as the value of PEC increased. Moreover, CU for wheat crop was significantly differed due to wheat cultivars, and Sids 1 consumed more water than the other tested wheat cultivars.

6- The lowest water use efficiency (WUE) was recorded under 1.4 PEC, comparable to the other tested PEC values. Values of PEC i.e. 1.2, 1.0 and 0.8 exhibited similar WUE values in first season, while in the second season, WUE tended to decrease as PEC value decreased. Gemmeiza 7 surpassed the other tested wheat cultivars to produce more grain yield per the consumed water unit, and this was true in the two seasons of study.

Key words: Irrigation scheduling, Wheat cultivars and Pan evaporation.

Fayoum J. Agric. Res. \& Dev., Vol. 21, No. 1, January, 2007 


\section{INTRODUCTION}

In Egypt, as many regions in the world, wheat is the most important cereal crop, but unfortunately, the local production did not meet the consumption owing to the increased population with limited both cultivated area and water resources. Thus, increasing both of wheat and water productivity are the most concern for crop and field irrigation specialists. The horizontal expansion means cultivating wheat in the newly reclaimed area while, the vertical expansion concerning increasing yield per the and water units and can be accomplished via improved agronomic practices such as sowing date, highyielding cultivars, irrigation management .....etc.

It is well known that the crop productivity is a function of soil moisture availability during the growing season. Khater et al. (1997) and Moussa and Abdel-Maksoud (2004) reported that No. of spikes $/ \mathrm{m}^{2}$, 1000-grain weight, straw and grain yields were reduced due to irrigation after higher soil moisture depletion. Moreover, stated that exposing wheat crop to late drought reduced water consumptive use and simultaneously increased water use efficiency.

Irrigation is a limiting factor in crop production in arid and semi arid regions and practicing irrigation timely and quantitatively is leading for more precise irrigation management. Early in USA, Jensen and Midleton (1965) scheduling crop irrigation via daily records of evaporation pan. In this respect, Eid et al. (1982) used the evaporation pan method to schedule irrigation for both wheat and Egyptian clover crops. Several field Attempts have been carried out and still continuous in order to find out the most proper coefficient used in irrigation scheduling of wheat crop, via daily accumulative records of class Apan, to maximize water productivity, (Rayan et al., 1999 in upper Egypt and El-Marsafawy - Samia, 2000 in Giza area).

The main objective of the present trial is to find out the impacts of different irrigation regimes, due to different coefficients for daily pan evaporation norms to select the most effective one resulted in improved growth, yield, yield components and water use efficiency for some wheat cultivars.

\section{MATERIALS AND METHODS}

Two field experiments were conducted during the two winter seasons of 2003/2004 and 2004/2005 at Giza Agric. Res. Station .Some of soil water constants and bulk density as well as meteorological data of the experimental site are presented in Tables (1) and (2), respectively .

Table (1). Soil moisture constants and bulk density of the experimental site at Giza Agricultural Research Station

\begin{tabular}{|c|c|c|c|c|}
\hline $\begin{array}{c}\text { Soil depth } \\
(\mathrm{cm})\end{array}$ & $\begin{array}{c}\text { Field capacity } \\
(\mathrm{wt} / \mathrm{wt} \%)\end{array}$ & $\begin{array}{c}\text { Wilting point } \\
(\mathrm{wt} / \mathrm{wt} \%)\end{array}$ & $\begin{array}{c}\text { Available soil } \\
\text { moisture(mm) }\end{array}$ & $\begin{array}{c}\text { Bulk density } \\
\left(\mathrm{gcm}^{-3}\right)\end{array}$ \\
\hline $0.0-15$ & 41.85 & 18.61 & 23.24 & 1.15 \\
\hline $15-30$ & 33.68 & 17.50 & 16.18 & 1.24 \\
\hline $30-45$ & 28.38 & 14.02 & 14.36 & 1.20 \\
\hline $45-60$ & 28.05 & 16.54 & 11.51 & 1.28 \\
\hline
\end{tabular}

The present trial aimed to find out the impacts of scheduling irrigation via different coefficients of daily norms of pan evaporation (Class A pan) on yield components and some water - yield relations for some wheat cultivars namely Sids 1, Gemmeiza 7, Sakha 93 and Giza 168. The experimental treatments were arranged in split-plot design with four replicates. The main plots were

Fayoum J. Agric. Res. \& Dev., Vol. 21, No. 1, January, 2007 
represented the irrigation scheduling according to pan-evaporation coefficients as follows:

1- Pan-evaporation coefficient of 1.4

2- Pan-evaporation coefficient of 1.2

3- Pan-evaporation coefficient of 1.0

4- Pan-evaporation coefficient of 0.8

Table (2). Some meteorological data* at Giza Agric. Res. Station, $2002 / 2003$ and $2003 / 2004$ seasons

\begin{tabular}{|c|c|c|c|c|c|c|c|c|}
\hline \multirow{2}{*}{ Month } & \multicolumn{7}{|c|}{$\mathbf{2 0 0 2 / 2 0 0 3}$ season } \\
\cline { 2 - 9 } & T max & T min & WS & RH & RF & SS & SR & E pan \\
\hline Nov & 26.8 & 15.3 & 1.8 & 72 & - & 8.2 & 326 & 3.2 \\
\hline Dec & 21.7 & 11.5 & 2.2 & 74 & 5.4 & 7.0 & 268 & 2.0 \\
\hline Jan & 19.8 & 10.9 & 1.9 & 64 & - & 7.0 & 280 & 2.2 \\
\hline Feb & 21.4 & 10.2 & 2.7 & 61 & 1.7 & 7.9 & 453 & 3.3 \\
\hline Mar & 23.9 & 11.2 & 2.3 & 59 & 2.6 & 8.6 & 441 & 3.5 \\
\hline Apr & 28.3 & 15.8 & 2.7 & 54 & - & 906 & 519 & 5.7 \\
\hline \multicolumn{7}{|c|}{$\mathbf{2 0 0 4 / 2 0 0 5}$ season } \\
\hline Nov & 25.5 & 16.3 & 1.1 & 69 & 1.3 & 8.2 & 326 & 2.5 \\
\hline Dec & 20.9 & 11.2 & 1.1 & 63 & 2.9 & 7.0 & 268 & 2.0 \\
\hline Jan & 19.9 & 9.3 & 1.8 & 59 & 1.9 & 7.0 & 280 & 2.0 \\
\hline Feb & 20.4 & 10.2 & 1.6 & 59 & 0.4 & 7.9 & 453 & 3.4 \\
\hline Mar & 24.5 & 13.3 & 1.5 & 57 & 0.4 & 8.6 & 441 & 4.2 \\
\hline Apr & 28.3 & 15.9 & 1.4 & 54 & - & 9.6 & 519 & 5.3 \\
\hline
\end{tabular}

* $\mathrm{T}$ max and $\mathrm{T} \min =$ maximum and minimum temperatures, $\mathrm{C}^{0} ; \mathrm{WS}=$ wind speed, $\mathrm{m} / \mathrm{sec}$; $\mathrm{RH}=$ relative humidity \% $\mathrm{RF}=$ rain fall, $\mathrm{mm} ; \mathrm{SS}=$ actual sunshine, $\mathrm{hr} ; \mathrm{SR}=$ solar radiation, $\mathrm{cal} / \mathrm{cm}^{2} /$ day $; \mathrm{Ep}=$ pan evaporation, $\mathrm{mm} /$ day

The sub-plots were assigned to the tested wheat cultivars. The sub -plot area was $10.5 \mathrm{~m}^{2}$ i.e. $1 / 400$ feddan. Sowing date was November, 15 in $1^{\text {st }}$ season and November, 20 in $2^{\text {nd }}$ season. Irrigation water was applied in the two sites of the following formula;

Available soil moisture, $\mathrm{mm}$ (to $60 \mathrm{~cm}$ depth of soil profile $)=$ Accumulative of daily pan - evaporation records $x$ Pan-evaporation coefficient

in Table (3).

Irrigation dates, under different Pan-evaporation coefficients, are shown

All of the agronomic practices i.e. sowing date, nitrogen fertilization, pest control ...etc were executed as recommended for wheat production in the area. The harvest was done as the plants reached the physiological ripening.

Water consumptive use $(\mathrm{Cu})$ :

Water consumptive use was determined via soil samples from the sub plots just before each irrigation and $48 \mathrm{hrs}$ later in addition at harvesting, in 15 $\mathrm{cm}$ increment system to $60 \mathrm{~cm}$ depth of the soil profile. The $\mathrm{Cu}$ was calculated according to Israelsen and Hansen (1962) as follows:

$\left.\boldsymbol{C u}=\underline{Q}_{100}^{\left(Q_{1}\right.}\right) \times \boldsymbol{D} X \boldsymbol{B d} \ldots \ldots \quad$ where

$\mathrm{Cu}=$ Water consumptive use, $\mathrm{mm}$

$\mathrm{D}=$ Soil layer depth , mm

Fayoum J. Agric. Res. \& Dev., Vol. 21, No. 1, January, 2007 
Foaad A.F. Khalil, et al.

$\mathrm{Bd}=$ Bulk density of soil layer, $\mathrm{gcm}^{-3}$

$\mathrm{Q}_{2}=$ Soil layer moisture content, wt $/ \mathrm{wt} \%, 48 \mathrm{hrs}$ post irrigation, and

$\mathrm{Q}_{1}=$ Soil layer moisture content, wt/wt \%, just before irrigation .

Water use effcicincy (WUE)

Water use efficiency,in the present work, wheat grains yield produced for 1 $\mathrm{m}^{3}$ of water consumed and estimated according to Vites ( 1965) as follows:

$$
\text { WUE }, \mathbf{k g} \text { grain } / \mathbf{m}^{3} \text { consumed water }=\frac{\text { Grain yield }, \mathrm{kg} / \mathrm{fed}}{\text { Water consumed }, \mathrm{m} 3 / \mathrm{fed}}
$$

Table (3). Date of applied irrigations under different coefficients of accumulative daily pan evaporation records in $2003 / 2004$ and $2004 / 2005$ seasons

\begin{tabular}{|c|c|c|c|c|c|c|c|c|}
\hline \multirow{2}{*}{$\begin{array}{c}\text { Irrigation } \\
\text { Regimes (pan } \\
\text { evaporation } \\
\text { coefficients) }\end{array}$} & \multicolumn{8}{|c|}{ Irrigation and dates } \\
\hline & Sowing & Mohayah & $2^{\text {nd }}$ & $3^{\mathrm{rd}}$ & $4^{\text {th }}$ & $5^{\text {th }}$ & $6^{\text {th }}$ & $7^{\text {th }}$ \\
\hline \multicolumn{9}{|c|}{$2003 / 2004$ season } \\
\hline 1.4 & Nov.22 & Dec. 15 & Jan.1 & Jan.22 & Feb.12 & Mar.2 & Mar.20 & Apr.6 \\
\hline 1.2 & Nov. 22 & Dec. 15 & Jan.5 & Jan.29 & Feb.21 & Mar.16 & Apr.6 & \\
\hline 1.0 & Nov.22 & Dec. 15 & Jan. 8 & Feb.4 & Mar.1 & Mar.30 & & \\
\hline 0.8 & Nov.22 & Dec. 15 & Jan.15 & Feb.12 & Mar.12 & & & \\
\hline \multicolumn{9}{|c|}{$2004 / 2005$ season } \\
\hline 1.4 & Nov. 22 & Dec. 15 & Jan.9 & Jan.26 & Feb.12 & Feb. 28 & Mar.14 & Apr.1 \\
\hline 1.2 & Nov.22 & Dec. 15 & Jan.12 & Jan.31 & Feb.17 & Mar.7 & Mar.29 & \\
\hline 1.0 & Nov.22 & Dec. 15 & Jan.16 & Feb.9 & Mar.3 & Mar.23 & & \\
\hline 0.8 & Nov. 22 & Dec. 15 & Jan.22 & Feb.17 & Mar.14 & & & \\
\hline
\end{tabular}

Growth, yield and some yield attributes:

Leaf area index was estimated at flowering stage for the different wheat cultivars under the adopted irrigation regimes. At harvesting, the plants of each entire sub-plot were sampled in order to determine straw and grain yield which converted to ton and ardab /fed, respectively. No of spikes $/ \mathrm{m}^{2}$ was estimated by counting all spikes per square meter selected in random from each sub-plot. Ten spikes were randomly taken, from each sub-plot, and No. of grains/spike and 1000-grain wt (g) were estimated. Data of growth, yield and yield components were subjected to statistical analysis of variance as described by Sendecor and Cochoran (1980). The mean values were compared according to Duncan's multiple relng test, Duncan (1955).

\section{RESULTS AND DISCUSSION 1- Plant height:}

Regarding irrigation regimes, data in Table (4) reveal a significant effect on plant height in both seasons of study. The tallest plants $(95.90$ and $97.77 \mathrm{~cm})$ was obtained under irrigating according to 1.4 pan evaporation coefficient (PEC), while the shortest plants $(85.02$ and $89.23 \mathrm{~cm})$ resulted from irrigating at 0.8 PEC treatment, and this was true in the two seasons of study.. These results are in agreement with those of Ali (1997) and Hefnawy and Wahba (2003). Data also clear out that, there are significant differences among wheat cultivars to influence plant height trait in both seasons. Gemmeiza 7 cultivar gave the tallest plants (93.68 and $94.89 \mathrm{~cm}$ ), while, Giza 168 gave the shortest ones (86.96 and 93.06) in the first and second seasons, respectively.. Such results

Fayoum J. Agric. Res. \& Dev., Vol. 21, No. 1, January, 2007 
IRRIGATION SCHEDULING FOR SOME WHEAT CULTIVARS

could be attributed to the genetic differences (Moussa and Abdel-Maksoud, 2004) reported the same results and justifications. The interaction between irrigation regimes and wheat cultivars was significant to alter such trait in both seasons, and the tallest plants were obtained for Gemmeiza 7 cultivar as irrigated with 1.4 PEC.

2- Leaf area index:

Data in Table (4) show that irrigation regimes significantly affected the leaf area index in the two seasons. The highest values of leaf area index (8.39) and (10.50) were obtained with irrigating according to 1.2 in the first season and with 1.4 PEC treatment in the second one, respectively. The lowest values (4.43 and 5.46) resulted from irrigating at 0.8 PEC treatment in first and second seasons, respectively. Similar results were obtained by Moustafa et al. (1996), Tawfiles et al. (1997) and Moussa and Abdel-Maksoud (2004). Data also reveal that the leaf area index was highly significant influenced due to the tested wheat cultivars in the first season. Gemmeiza 7 cultivar significantly exceeded the other cultivars, while the lowest value was obtained by Giza 168 cultivar and these findings were true in the two seasons of study. Such differences may be attributed to the variability among the wheat cultivars. These results are in agreement with those obtained by Ali (1997), Abd ElMajeed et al. (1998), Abd El-All-Azza (1999) and Moussa and AbdelMaksoud (2004). The interaction between irrigation regimes and wheat cultivars exerted significant effect to influence leaf area index in both seasons. Gemmeiza 7 cultivar, under 1.4 and 1.2 PEC irrigation treatments, exhibited higher values (9.90 and 11.95) in both seasons, respectively.

\section{3- Number of grains/spike:}

Data in Table (4) show that the adopted irrigation treatments significantly affected number of grains/spike trait in the two seasons of study. The highest number of grains/spike (63.73 and 60.52) were obtained under irrigating with 1.2 PEC, whereas the lowest values (49.41 and 52.31) were resulted from 0.8 PEC treatment in first and second seasons, respectively. This may be due to less available soil moisture in the root zone under 0.8 PEC throughout the growing season. Similar results were obtained by Moustafa $\boldsymbol{e t}$ al. (1996), Tawfiles et al. (1997) and Moussa and Abdel -Maksoud (2004) who found that the soil drought reduced number of kernels/spike which is the most yield components negatively affected by drought stress conditions. Moreover, Ali (1997) reported that, the number of kernels/spike were increased as irrigation frequency increased from 3 to 4 irrigations. Data also indicated that number of grains/spike trait was highly significant influenced by the tested wheat cultivars. Gemmeiza 7 cultivar significantly exceeded the other cultivars, while the lowest values were obtained by Giza 168 cultivar and this true in both seasons of study. Such differences in number of grain/spike trait may be due to variability among the wheat cultivars. These results are in agreement with those obtained by Ali (1997), Abd El-Majeed et al. (1998), Abd El-All-Azza (1999) and Moussa and Abdel-Maksoud (2004). The interaction between irrigation regimes and wheat cultivars had a significant effect on number of grains/spike in both seasons, and Gemmeiza 7 cultivar as irrigated according to 1.2 PEC treatment gave the high values (68.35 and 65.35) in first and second seasons, respectively.

Fayoum J. Agric. Res. \& Dev., Vol. 21, No. 1, January, 2007 


\section{4- 1000-grain weight :}

As shown in Table (4), 1000-grain weight trait was significantly influenced by the adopted irrigation regimes in the second season only. The highest value of 1000 -grain weight $(55.24 \mathrm{~g})$ was obtained under irrigating at 1.2 PEC treatment, which gradually tended to be reduced to, 53.39, 51.82 and $47.73 \mathrm{~g}$ with irrigating at $1.4,1.0$ and $0.8 \mathrm{PEC}$ treatments, respectively. In the first season the same trend was observed, however, the difference did not reach the significance level. These results are crop with those obtained by El-Kalla $\boldsymbol{e t}$ al. (1995), Sonia et al. (1996) and Moussa and Abdel-Maksoud (2004) who reported that the 1000-grain weight tended to reduce as soil moisture availability decreased. The differences in 1000-grain weight among the wheat cultivars was significant in both seasons. The highest 1000-grain weight $(58.97$ and $59.78 \mathrm{~g}$ ) was obtained from Gemmeiza 7, while Giza 168 produced the lowest values (43.05 and $46.06 \mathrm{~g}$ ) in first and second seasons, respectively. Similar results were obtained by Shalaby et al. (1992) and Moussa and AbdelMaksoud (2004). The interaction between irrigation regimes and wheat cultivars was significant to affect 1000-grain weight in both seasons and irrigating Gemmeiza 7 according to 1.2 in the first season and 1.4 PEC in the second one gave the heaviest weight of 1000-grain which reached 63.30 and $64.35 \mathrm{~g}$, respectively.

5-Number of spikes $/ \mathrm{m}^{2}$ :

The results in Table (5) reveal that irrigation treatments differently affected number of spikes $/ \mathrm{m}^{2}$ in 2003/2004 and 2004/2005 seasons. The highest number of spikes $/ \mathrm{m}^{2}$ (317.1) was obtained under 1.0 PEC irrigation in the first season, while in the second season the highest number of spikes $/ \mathrm{m}^{2}(267.6 \mathrm{~g})$ was achieved due to irrigating at 1.2 PEC irrigation treatment. These results are in full agreement with those of El-Kalla et al. (1995), Hefnawy and Wahba (2003) and Moussa and Abdel-Maksoud (2004). Data in Table (5) also indicated that wheat cultivars were varied significantly in number of spikes $/ \mathrm{m}^{2}$ trait. Sids1 and Gemmeiza 7 cultivars gave the highest number of spikes $/ \mathrm{m}^{2}$ in the first and second seasons, respectively, while Giza 168 cultivar gave the lowest value in both seasons. These results are in harmony with those of ElKalla et al. (1995), Hefnawy and Wahba (2003) and Moussa and AbdelMaksoud (2004). The interaction between irrigation regimes and wheat cultivars was significant in both seasons and Gemmeiza 7 and Sids 1 cultivars as irrigated according to 1.0 and 1.4 PEC which gave the highest number of spikes $/ \mathrm{m}^{2}$ in the first and second seasons, respectively.

\section{6- Straw yield:}

Data in Table (5) show that irrigation treatments significantly affected straw yield in both seasons. The highest values (7.05 and 6.01 ton/fed) were obtained from irrigating at 1.4 PEC treatment, in the first and second seasons and then tended to be gradual by reduced as irrigation was scheduled at 1.2, 1.0 and 0.8 PEC. Abou-Khadrah et al. (1999) stated that the increase in straw yield as amount of irrigation water increased might be due to the increase of yield components such as number of productive tillers and growth attributes. Data also, reveal significant differences among wheat cultivars in both seasons and Gemmeiza 7 gave the highest straw yield in the two seasons of study. These findings are similar to those obtained by Abou-Khadrah et al. (1999). The interaction between irrigation regimes and wheat cultivars was significant in both seasons and Gemmeiza 7 cultivar as irrigated according to 1.4 PEC that gave the highest straw yield.

Fayoum J. Agric. Res. \& Dev., Vol. 21, No. 1, January, 2007 
IRRIGATION SCHEDULING FOR SOME WHEAT CULTIVARS..... 228

Table 4

Fayoum J. Agric. Res. \& Dev., Vol. 21, No. 1, January, 2007 
Foaad A.F. Khalil, et al.

rra

Table 5

Fayoum J. Agric. Res. \& Dev., Vol. 21, No. 1, January, 2007 


\section{7- Grain yield:}

The results in Table (5) show that the grain yield was significantly influenced due to irrigation regimes in the two growing seasons. Wheat grain yield was higher as the plants were irrigated according to 1.2 PEC with increases comprised $0.69,12.31$ and $33.31 \%$ more than those under $1.4,1.0$ and 0.8 PEC treatments in the first season, respectively. The same trend was observed in the second season with corresponding increase percentages reached to 5.42, 16.69 and 35.81 in the same order. These results are in agreement with those obtained by El-Marsafawy-Samia (2000) who found that the maximum wheat grain yield was achieved as the irrigation was scheduled at 1.0 PEC which exceeded those resulted from irrigating at 0.8 and 0.6 PEC treatments. Data in Table (5) show that, the evaluated 4 wheat cultivars were differed significantly in their potentiality and Gemmeiza 7 was the leading one in both seasons. The differences in the productivity of wheat cultivars were also reported by Shalaby et al. (1992), Abd El-Majeed et al. (1998), Abd El-AllAzza (1999), Hefnawy and Wahba (2003) and Moussa and Abdel-Maksoud (2004). The results in Table (5) indicate that there is a significant effect for the interaction between irrigation regimes and wheat cultivars in both seasons to affect the grain yield, and Gemmeiza 7 cultivar which gave the highest grain yield as irrigated according 1.2 PEC treatment in both seasons.

\section{Crop- water relations}

\section{1-Water Consumptive use (CU):}

It is obvious that irrigation numbers were increased as the value of pan evaporation coefficient (PEC) increased since the wheat plants received 6, 5, 4 and 3 watering under 1.4, 1.2, 1.0 and 0.8 PEC treatments, respectively, besides sowing and Mohayah ones, and those finding were true in the two seasons of study (Table, 3). Data in Table (6) reveal that, regardless wheat cultivars, water consumptive use was increased as PEC value increased since the $\mathrm{Cu}$ value under 1.4 PEC in the first season was increased by $9.0,23.03$ and $45.59 \%$ more than those under 1.2, 1.0 and 0.8 PEC treatments, respectively. In the second season, similar trend was observed with increases reached to 8.23, 19.07 and $41.69 \%$, respectively in the same order. These results may be attributed to that the value of PEC increased to the number of irrigation increased and the soil moisture was more available for extraction by plant roots and soil surface evaporation as well. Rayan et al. (1999), El-Marsakawy-Samia (2000) and Moussa and Abdel-Maksoud (2004) came to the same results and justification. In connection, Oweis et al. (2000) found that evapotranspiration (ET) for wheat was increased as supplemental irrigation increased. Regarding wheat cultivars under investigation, data clear out that water consumptive use was differentially affected due to wheat cultivars and sids 1 cultivar consumed more water than the other tested cultivars and this trend was observed in the two seasons of study. Moussa and Abdel-Maksoud (2004) previously reported the variation among wheat cultivars to affect water consumptive use character.

Fayoum J. Agric. Res. \& Dev., Vol. 21, No. 1, January, 2007 
Foaad A.F. Khalil, et al.

Table (6). Water consumptive use $\left(\mathrm{m}^{3} /\right.$ fed.) and Water use efficiency $\left(\mathrm{kg} / \mathrm{m}^{3}\right)$ for wheat cultivars under different irrigation regimes in 2003/2004 and 2004/2005 seasons

\begin{tabular}{|c|c|c|c|c|c|c|c|c|c|c|}
\hline \multirow{3}{*}{$\begin{array}{c}\text { Season } \\
\text { Irrigation } \\
\text { regime } \\
(\mathrm{PEC})\end{array}$} & \multicolumn{5}{|c|}{$2003 / 2004$} & \multicolumn{5}{|c|}{$2004 / 2005$} \\
\hline & \multicolumn{10}{|c|}{ Water consumptive use ( $\left.\mathrm{m}^{3} / \mathrm{fed}.\right)$} \\
\hline & $\begin{array}{c}\text { Sids } \\
1\end{array}$ & $\begin{array}{c}\text { Gemm- } \\
\text { eiza } \\
7 \\
\end{array}$ & $\begin{array}{c}\text { Sakha } \\
93\end{array}$ & $\begin{array}{c}\text { Giza } \\
168\end{array}$ & Aver. & $\begin{array}{c}\text { Sids } \\
1\end{array}$ & $\begin{array}{c}\text { Gemm- } \\
\text { eiza } \\
7 \\
\end{array}$ & $\begin{array}{c}\text { Sakha } \\
93\end{array}$ & $\begin{array}{c}\text { Giza } \\
168\end{array}$ & Aver. \\
\hline 1.4 & 1759 & 1734 & 1628 & 1612 & 1683 & 1818 & 1748 & 1693 & 1632 & 1723 \\
\hline 1.2 & 1600 & 1546 & 1524 & 1504 & 1544 & 1684 & 1618 & 1541 & 1542 & 1592 \\
\hline 1.0 & 1446 & 1398 & 1330 & 1296 & 1368 & 1537 & 1500 & 1404 & 1348 & 1447 \\
\hline 0.8 & 1212 & 1200 & 1134 & 1078 & 1156 & 1264 & 1240 & 1207 & 1154 & 1216 \\
\hline Average & 1504 & 1470 & 1404 & 1373 & 1438 & 1576 & 1527 & 1461 & 1415 & 1495 \\
\hline \multicolumn{11}{|c|}{ Water use efficiency $\left(\mathrm{kg} / \mathrm{m}^{3}\right)$} \\
\hline 1.4 & 1.54 & 1.78 & 1.52 & 1.38 & 1.56 & 1.23 & 1.32 & 1.28 & 1.18 & 1.25 \\
\hline 1.2 & 1.54 & 2.17 & 1.65 & 1.53 & 1.72 & 1.34 & 1.35 & 1.46 & 1.46 & 1.40 \\
\hline 1.0 & 1.60 & 2.28 & 1.60 & 1.33 & 1.70 & 1.30 & 1.47 & 1.42 & 1.33 & 1.35 \\
\hline 0.8 & 1.71 & 1.89 & 1.68 & 1.57 & 1.71 & 1.39 & 1.45 & 1.39 & 1.27 & 1.38 \\
\hline Average & 1.60 & 1.03 & 1.61 & 1.45 & 1.68 & 1.32 & 1.40 & 1.39 & 1.31 & 1.35 \\
\hline
\end{tabular}

\section{2-Water Use Efficiency (WUE):}

Water use Efficiency, in the present work, means $\mathrm{kgs}$ of wheat grains produced due to the unit of consumed water. On this basis, data in Table (6) reveal that regardless wheat cultivars, WUE value was lesser as irrigation was practiced according to 1.4 PEC than the other tested PEC treatments. The WUE value was the highest under 1.2 PEC treatment in the two seasons of study. The WUE values under irrigating at 1.2, 1.0 and 0.8 PEC were similar in the first season, while in the second season, decreasing the PEC value resulted in lower WUE values. In connection, El-Marsafawy-Samia (2000) found that the highest WUE value for wheat was achieved as irrigation practiced according to 1.0 PEC. Nevertheless, Khater et al. (1997) and Moussa and Abdel-Maksoud (2004) reported that WUE tended to increase as irrigation was applied after higher soil moisture depletion. Furthermore, Hefnawy and Wahba (2003) stated that WUE for wheat cultivars seemed to increase due to reducing number of irrigation. Regarding wheat cultivars, WUE was differently influenced due to the cultivars under study and Gemmeiza 7 proved to be superior to produce the highest grain yield per the unit of consumed water, and this finding was true in the two seasons of study. Similar results concerning WUE character as affected by wheat cultivars were recorded by Moussa and Abdel-Maksoud (2004). Gemmeiza 7 cultivar exhibited higher WUE values with irrigating at 1.0 PEC treatment in the two seasons of study.

On conclusion, under Giza area condition, it is advisable to sow Gemmeiza 7 wheat cultivar and scheduling the irrigation according to 1.2 PEC since most of growth, yield and yield components traits and water use efficiency were enhanced with such interaction.

Fayoum J. Agric. Res. \& Dev., Vol. 21, No. 1, January, 2007 


\section{REFERENCES}

Abd El-All-Azza, M. (1999). Performance of some New Long Spike Wheat Genotypes Under Different Cultural Treatments. M.Sc. Thesis, Fac. of Agric. Moshtohor, Zagazig Univ., Egypt.

Abd El-Majeed, S. A; A. M. Moussad and A. A.Khatab (1998) . Verification of Improved Wheat Cultivars at Middle Egypt. Nile Valley and Red sea Coordination Meeting, pp..12-26, A.R.C. Egypt .

Abou-Khadrah, S.H.; S.A. Abd El-Hafez; F.A. Sorour and A.Z. El-Bably (1999). Effect of soil moisture stress on wheat production, its components and nutrient uptake. $3^{\text {rd }}$ Conf. of Farm Irrig. And Agroclimat., Giza, Egypt paper No. 47.

Ali, S.A. (1997). Effect of some agricultural practices on growth., yield and yield Components of wheat. Ph. D. Thesis, Fac. Agric., El-Menia Univ., Egypt.

Duncan, B.D. (1955). Multiple rang and Multiple F test. Biometrics, 11: 1-42.

Eid, H.M.; M.A. Metwaly and F.M. Mahrous (1982). Evaporation pan as index to consumptive use of water and scheduling irrigation in some field crops. Agric. Res. Rev., Vol. 60 No. 5.

El-Kalla, S.E.A.E.; A.A. Leilah; A.H.Basiony and S.M. Hussein (1995). Effect of irrigation and foliar nutrition treatments on growth and yield of some wheat cultivars under Al-Arish area conditions. Proc. $6^{\text {th }}$ Conf. Agron., AlAzhar Univ., Cairo, 1:362-378.

El-Marsafay-Samia M. (2000). Scheduling irrigation of wheat crop under different phosphorus fertilizer application times in Middle Egypt . Proc. $5^{\text {th }}$ Conference - Meteorology \& Sustainable development :182-195 .

Hefnawy, F.A. and M.F. Wahba (2003). Effect of water stress in late growth stages of some wheat cultivars. J. Agric Sci. Mansoura Univ., 28(2): 729745 .

Israelsen, O.W. and V.E. Hansen (1962). Irrigation Principles and Practices $.3^{\text {rd }}$ ed., John Wiley and Sons Inc., New York.

Jensen, M.C. and J.E. Midleton (1965). Scheduling irrigation from pan evaporation. Washington Agric. Exp. Station, Collage of Agric., Washington State Univ., Circular 386, revised 1965.

Khater, A.N.; H.H. Abdel-Maksoud and H.M. Eid (1997). Response of some wheat cultivars and their water relations to different irrigation levels in middle Delta . Egypt .J. Appl. Sci. 12(5): 142-158.

Moussa, A.M. and H.H. Abdel-Maksoud (2004). Effect of soil moisture regime on yield and its components and water use efficiency for some wheat cultivars. Annals Agric. Sci., Ain Shams Univ., 49(2): 515-530

Moustafa, M.A.; L.Boersma and W.E.Kronstaed (1996). Response of four spring wheat cultivars to drought stress . Crop Sci., 36: 982-986.

Oweis, T., H. Zhang and M. Pala (2000). Water use efficiency of rainfed and irrigated bread wheat in Mediterranean environment. Agron. J., 92: 231-238

Rayan, A.A.; S.M. El-Marsafawy and K.A.Mohamed (1999) . Response of wheat varieties to different sowing dates and irrigation regimes in Upper Egypt. $3{ }^{\text {rd }}$ Conf. on Farm Irrigation and Agroclimatology, Giza, Paper No. 44.

Sendecor, W.G. and W.G. Cochran (1980). Statistical Methods. $6^{\text {th }}$ edition, Oxford and J.B.H. publishing Co., U.K.

Shalaby, E.E.; M.M. El-Ganbeehy and M.H. El-Sheikh (1992). Performance of wheat genotypes under drought stress. Alex. J.Agric. Res., 37(1): 33-51.

Fayoum J. Agric. Res. \& Dev., Vol. 21, No. 1, January, 2007 
Foaad A.F. Khalil, et al.

Sonia, D.; L. Sylvie and S.S. Harqurdeep (1996). Induction male sterility in wheat by melodic stage water deficit is preceded by a decline in inverse activity and changes in carbohydrate metabolism in anthers. Plant Physiol, 111: 137-145.

Tawfiles, M.B.; M.G. Mossad and A.M. Abdel-Shaffi Ali (1997). Effect of irrigation intervals on wheat grain yield in Upper Egypt new lands. Annual Coordination Meeting. Agric. Res. Center. Field crops Res. Inst. Giza, Egypt, pp. 138-143.

Vites, F.G.Jr (1965). Increasing water use efficiency by soil management . Amer. Soc. Agron., Madison, Wisc. P. 259-274.

Wang, X.; L. Mengyu; L. Xiaonasn; X.X. Xinhai and M. Xaxuesen (1991). Water use efficiency in agric. Proceedings of the Binational. China - Israel workshop. April 22-26, pp. 136-146.

$$
\begin{aligned}
& \text { جدولة الرى لبعض اصناف القمح باستخذام بيانات وعاء البخر القياسى ولئي }
\end{aligned}
$$

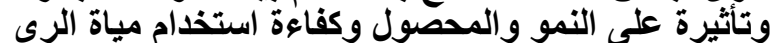

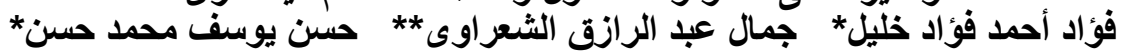

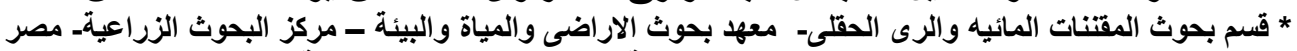

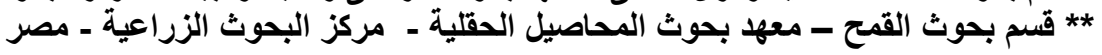

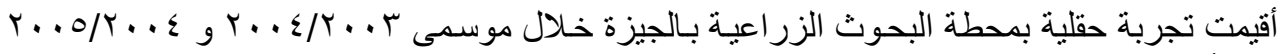

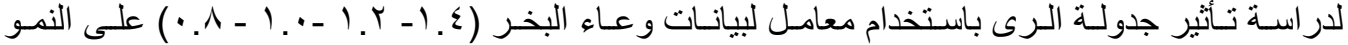

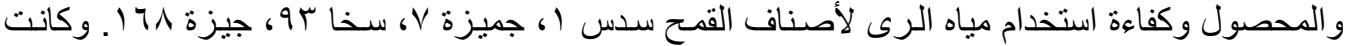

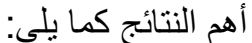

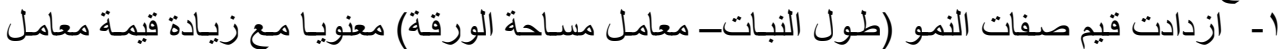

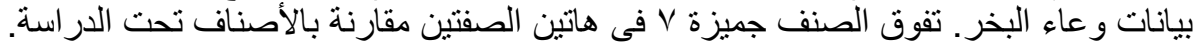

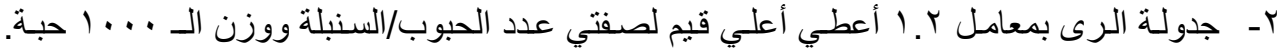

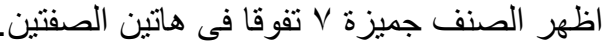

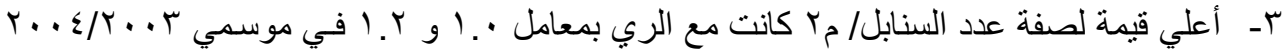

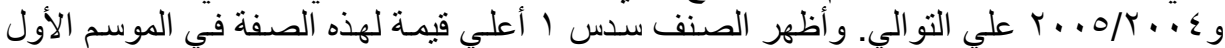

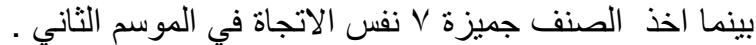

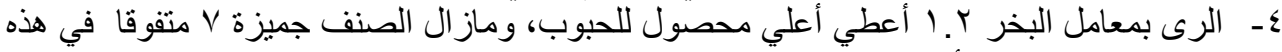

$$
\begin{aligned}
& \text { الصفة علي جميع الأصناف تحت الأل الدراسة. } \\
& \text { 0ـ صفات النمو و المحصول وكذا مكوناته نأثرت معنويا بتفاعل مستويات الرى وأصناف القمح تحت } \\
& \text { الدر اسة. } \\
& \text { T- - زاد عدد الريات و كذا الاستهلاك المائي لأصناف القمح تحت الدر اسـة بزيادة قيمة معامل بيانـات }
\end{aligned}
$$

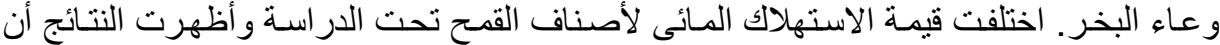

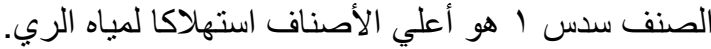

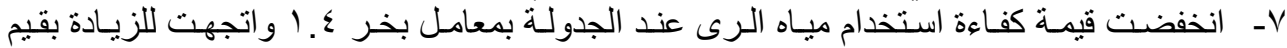

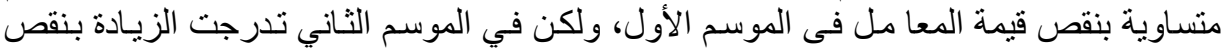

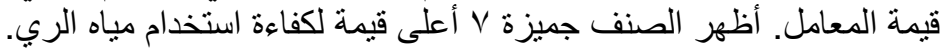

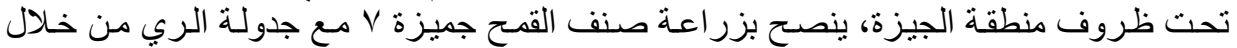

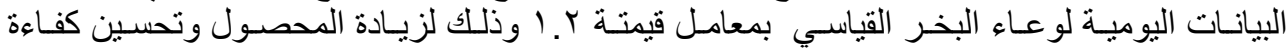

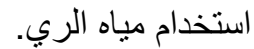

Fayoum J. Agric. Res. \& Dev., Vol. 21, No. 1, January, 2007 